\title{
Magnetic signatures of natural and anthropogenic sources of urban dust aerosol
}

\author{
Haijiao Liu ${ }^{1,2}$, Yan Yan ${ }^{3}$, Hong Chang ${ }^{1,4}$, Hongyun Chen ${ }^{5}$, Lianji Liang ${ }^{6}$, Xingxing Liu ${ }^{1,4}$, Xiaoke Qiang $^{1,4}$, and \\ Youbin Sun ${ }^{1,4,7}$ \\ ${ }^{1}$ State Key Laboratory of Loess and Quaternary Geology, Institute of Earth Environment, Chinese Academy of Sciences, \\ Xi'an, 710061, China \\ ${ }^{2}$ College of Earth Science, University of Chinese Academy of Sciences, Beijing, 100049, China \\ ${ }^{3}$ Key Laboratory of Ocean and Marginal Sea Geology, Guangzhou Institute of Geochemistry, Chinese Academy of Sciences, \\ Guangzhou, 510640, China \\ ${ }^{4}$ CAS Center for Excellence in Quaternary Science and Global Change, Chinese Academy of Sciences, Xi'an, 710061, China \\ ${ }^{5}$ Research Center for Loess and Global Changes, Institute of Hydrogeology and Environmental Geology, \\ Chinese Academy of Geological Sciences, Shijiazhuang, 050803, China \\ ${ }^{6}$ College of Architecture and Civil Engineering, Beijing University of Technology, Beijing, 100124, China \\ ${ }^{7}$ Institute of Global Environmental Change, Xi'an Jiaotong University, Xi' an, 710049, China
}

Correspondence: Youbin Sun (sunyb@ieecas.cn)

Received: 7 May 2018 - Discussion started: 18 June 2018

Revised: 8 December 2018 - Accepted: 26 December 2018 - Published: 21 January 2019

\begin{abstract}
The characteristics of urban dust aerosols and the contributions of their natural and anthropogenic sources are of scientific interest as well as being of substantial sociopolitical and economic concern. Here we present a comprehensive study of dust flux, magnetic parameters, magnetic particulate morphology, and elemental compositions of atmospheric dustfall originating from natural dust sources in East Asia and local anthropogenic sources in Xi'an, China. The results reveal a significant inverse relationship between seasonal variations of dust flux and magnetic susceptibility $(\chi)$. By comparing dust flux and $\chi$ records, the relative contributions of dust from local anthropogenic sources are estimated. Analyses using scanning electron microscopy (SEM) combined with energy dispersive spectroscopy (EDS) indicate that magnetic particulate from different sources has distinct morphological and elemental characteristics. Detrital magnetic particles originating from natural sources are characterized by relatively smooth surfaces with $\mathrm{Fe}$ and $\mathrm{O}$ as the major elements and a minor contribution from Ti. The anthropogenic particles have angular, spherical, aggregate, and porous shapes with distinctive contributions from marker elements, including $\mathrm{S}, \mathrm{Cr}, \mathrm{Cu}, \mathrm{Zn}, \mathrm{Ni}, \mathrm{Mn}$, and $\mathrm{Ca}$. Our results demonstrate that this multidisciplinary approach is effective
\end{abstract}

in distinguishing dust particles derived from distant natural sources and local anthropogenic sources and for the quantitative assessment of contributions from the two end-members.

\section{Introduction}

Urban dust aerosols, comprising both natural and anthropogenic contributions with complex morphological and physiochemical characteristics, have become a focus of study in global climate change and regional air pollution (Wilson et al., 2002). Natural dust is derived primarily from longrange transport with minor local soil contributions and often causes dust events, including sandstorms, suspended dust, and blown-sand weather (Sun et al., 2001; Zhang et al., 2003; Chen et al., 2004; Kan et al., 2007; Baddock et al., 2013); it has an adverse effect on local air quality (Wang et al., 2004; Ginoux et al., 2004). Anthropogenic dust produced by human activities is characterized by high concentrations of toxic heavy metals (e.g., $\mathrm{Pb}, \mathrm{Zn}, \mathrm{Co}, \mathrm{Cr}, \mathrm{Ni}$, and $\mathrm{As}$ ), which has a long-lasting and deleterious impact on the local environment and human health (Zdanowicz et al., 2006; Qiao et al., 2013; Lu et al., 2014; Lee et al., 2015). 
Airborne ultrafine particulate matter (e.g., $\mathrm{PM}_{2.5}$ and $\mathrm{PM}_{1}$ ) can enter the alveolar region and blood circulatory system, leading to health issues and even death (Brunekreef and Holgate, 2002; Nel et al., 2006; Pickrell et al., 2009; Maher et al., 2013; Elser et al., 2016). Moreover, anthropogenic dust is an important medium for the formation of secondary pollutants and plays a significant role in the formation of haze events (Hanisch and Crowley, 2001; Li et al., 2001; Lee et al., 2002; Usher et al., 2002; Finlayson-Pitts et al., 2003; Rubasinghege and Grassian, 2009; Takeuchi et al., 2010; Wu et al., 2011; Huang et al., 2014). Consequently, it is important to distinguish the characteristics and contributions of natural and anthropogenic dust in urban aerosols to formulate effective policies for dust pollution abatement and improving air quality.

Natural and anthropogenic contributions to urban dust aerosols are usually assessed quantitatively using geochemical and magnetic methodologies (Gorden, 1988; Xie et al., 1999; Gomez et al., 2004; Spassov et al., 2004; Kim et al., 2009; Feng et al., 2012). Geochemical methods typically involve source apportionment and the contribution assessment of representative heavy metal elements using statistical methods such as chemical mass balance (CMB) (Chow et al., 2002; Gupta et al., 2007) and factor analysis (FA) (Harrison et al., 1997a; Salvador et al., 2004). Pb, Fe, Zn, Cr, Cd, $\mathrm{Ni}, \mathrm{Ba}$, and $\mathrm{Sb}$ are frequently used as marker elements for vehicle emissions (Huang et al., 1994; Adachi and Tainosho, 2004; Meza-Figueroa et al., 2007), while Hg, Pb, Mn, Cr, Co, $\mathrm{Cu}, \mathrm{Cd}$, and $\mathrm{Ni}$ are regarded as indicators of coal combustion (Vouk and Piver, 1983; Pacyna and Pacyna, 2001; Sushil and Batra, 2006).

Since magnetic measurements are rapid, inexpensive, and nondestructive, environmental magnetism is increasingly being used as an effective approach to study urban dust pollution (Maher, 1998; Hoffmann et al., 1999). By combining magnetic properties with morphological features (Muxworthy et al., 2001; Urbat et al., 2004; Blaha et al., 2008a) as well as heavy metal (Hunt et al., 1984; de Miguel et al., 1997; Blaha et al., 2008b; Maher et al., 2008) and backtrajectory characteristics (Wehner et al., 2008; Li et al., 2009; Fleming et al., 2012), the provenance, transport routes, and spatial distribution of polluted dust aerosols can be investigated. This multidisciplinary approach is becoming a popular means of urban pollution monitoring and assessment (Jordanova et al., 2014; Stein et al., 2015; Yan et al., 2015a; Bourliva et al., 2016).

Using environmental magnetic techniques to assess pollution levels and sources, different forms of urban dust aerosols in East Asia have been studied, including atmospheric dustfall, street dust, leaf dust, inhalable particulate matter, and surface soil. For example, spatial and temporal pollution patterns were quantitatively estimated from seasonal fluctuations of the concentration and grain size of magnetic particles in urban roadside dust (Kim et al., 2007, 2009). A high correlation between magnetic parameters (magnetic susceptibil- ity and saturation isothermal remanence, i.e., $\chi$ and SIRM) and heavy metal concentrations in street dust, polluted farmland soil, and atmospheric dustfall was observed, indicating that these magnetic parameters can be employed as effective proxies to assess heavy metal pollution (Zhang et al., 2011, 2012a, b; Qiao et al., 2013). SIRM characteristics of roadside leaves were shown to reflect spatial variations of magnetic particles in urban dustfall (Quayle et al., 2010; Hansard et al., 2011, 2012; Maher et al., 2013; Kardel et al., 2012). Although morphology, grain size, mineral, and element analyses were utilized in previous works, there are no studies that systematically compare magnetic signatures of natural dust, urban dust aerosol, and polluted dust from source to sink.

This study systematically collected surface sediments from potential dust sources in East Asia, urban dust aerosols in Xi'an, including atmospheric dustfall (over five consecutive years) and street dust, and typical anthropogenic pollutants such as vehicle exhaust and fly ash. Morphology and elemental compositions of magnetic particles in representative samples were analyzed to facilitate a thorough sourcesink comparison. Our results indicate that natural and anthropogenic contributions to urban dust aerosols can be differentiated using a combination of their magnetic, morphological, and elemental characteristics.

\section{Sampling and methods}

\subsection{Sampling}

Surface sediments were collected in potential dust source regions of East Asia, including the northern Chinese deserts (the Badain Juran and Tengger Desert), the Taklimakan Desert, Mongolian Gobi, and Tibetan Plateau (Fig. 1a). Fine-grained materials were collected from alluvial fans, dry riverbeds, lake basins, and drainage depressions within Gobi-sandy deserts at intervals of 100 to $200 \mathrm{~km}$ (Fig. 2ad). To better understand the different sedimentary characteristics, 48 samples from the northern Chinese deserts, 50 samples from the Taklimakan Desert, 23 samples from the Mongolian Gobi, and 32 samples from the Tibetan Plateau were selected for magnetic measurements. Locations of the samples are shown in Fig. 1a. Detailed descriptions were given in Sun et al. (2013).

A total of 68 street dust samples were collected from parks, construction sites, commercial streets, and residential areas in Xi'an following a $3 \times 4 \mathrm{~km}$ grid spanning approximately $30 \mathrm{~km}$ from west to east and $20 \mathrm{~km}$ from north to south (Fig. 1b). The sampling grid covers a range of different functional areas in Xi'an, including the Industrial District, Commercial District, Cultural District, Ecological District, and Han Chang' an city ruins park. We also collected four typical anthropogenic pollutant samples in June 2017, including one sample of exhaust from several vehicles, one sample of fly ash from a dust bag of electrostatic precipita- 


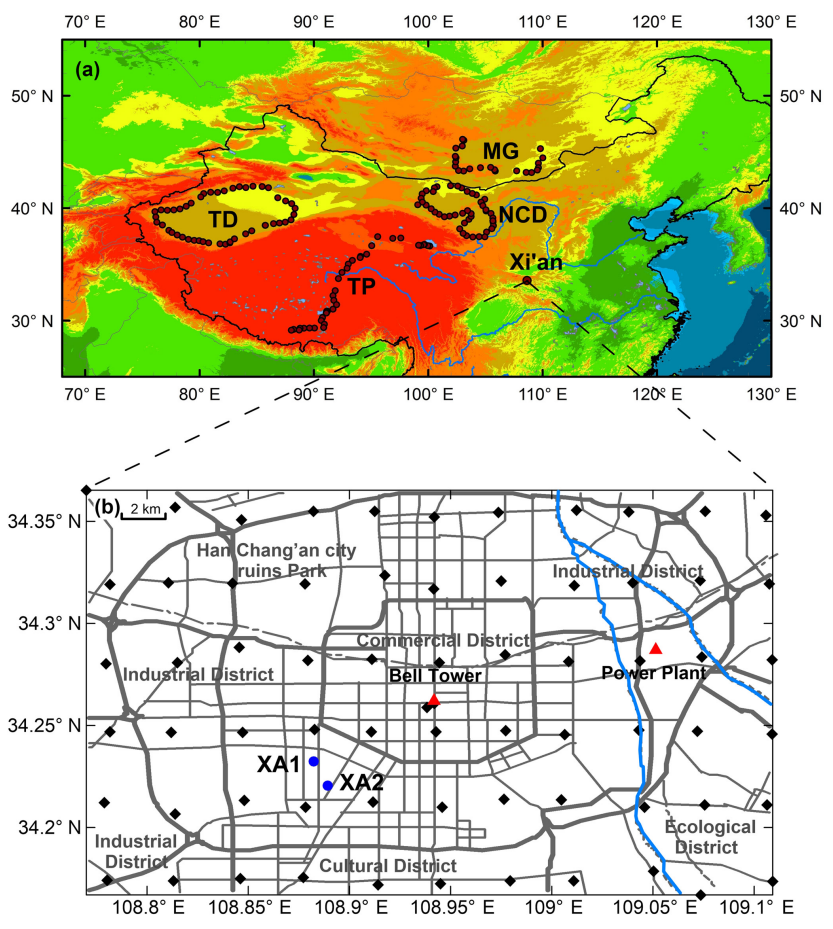

Figure 1. Locations of natural surface sediments in the East Asian sources (a) and urban dust samples in Xi' an (b). NCD - northern Chinese deserts, MG - Mongolian Gobi, TD - Taklimakan Desert, and TP - Tibetan Plateau. Black diamonds are street dust sampling sites; blue dots are samples of consecutive atmospheric dustfall (XA1 at the Institute of Earth Environment, Chinese Academy of Sciences; XA2 at the Xinxinjiayuan residential community); red triangles are typical heavily polluted sites, including the Bell Tower in an area of high traffic density and the Baqiao thermal power plant.

tors at the Baqiao thermal power plant, one street dust sample from the Bell Tower in downtown Xi' an, which experiences daily traffic jams, and one street dust sample near the Baqiao thermal power plant where coal burning is the leading pollution factor. The locations of these samples are shown in Fig. 1b.

Atmospheric dustfall collectors were placed on the top of a four-story building at the Institute of Earth Environment, Chinese Academy of Sciences, $\sim 10 \mathrm{~m}$ above the ground surface, and a 15-story building inside the Xinxinjiayuan residential community, $\sim 50 \mathrm{~m}$ above the ground surface (Fig. 2e, f). The sampling sites situated in southwest Xi' an consist primarily of commercial and residential districts. Samples were collected using the wet-collection method (Qian and Dong, 2004) at time intervals of 3-5 days in spring and 6-7 days in other seasons. Detailed sampling procedures were reported by Yan et al. (2015a, b); 733 samples were collected from March 2009 to March 2014. Dust flux (DF, $\left.\mathrm{g} \mathrm{m}^{-2} \mathrm{day}^{-1}\right)$ is calculated as follows:

$\mathrm{DF}=W /(A \times T)$,

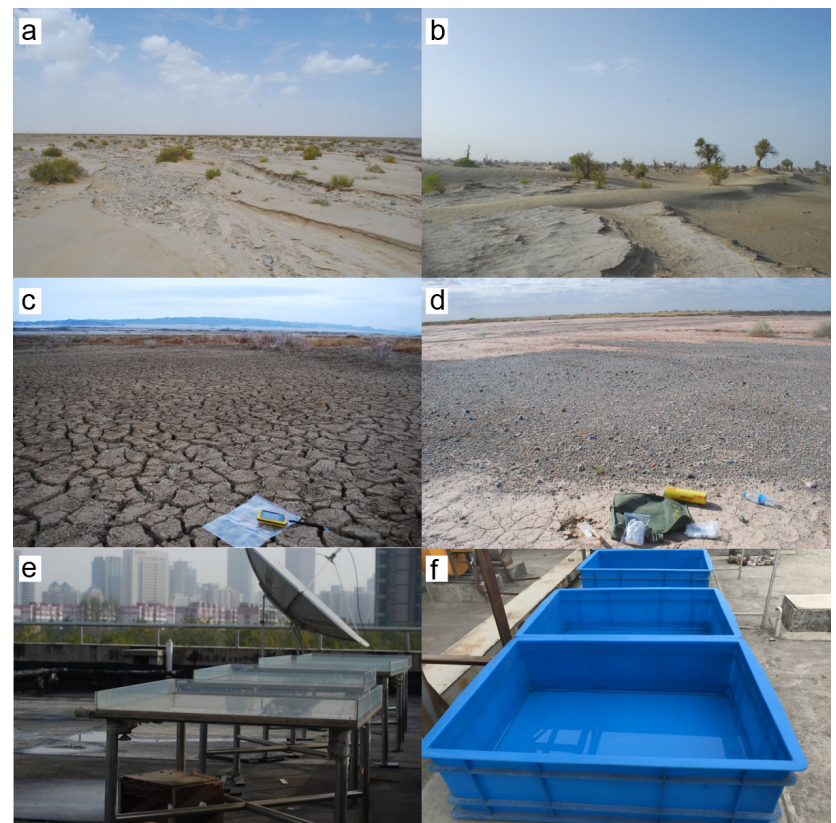

Figure 2. Sampling sites of natural surface sediments in a dry riverbed (a), desert margin (b), drainage depressions within sandy desert (c) and Gobi desert (d), and atmospheric dustfall at XA1 (e) and XA2 (f).

where $W$ is the sample weight in $\mathrm{g}, A$ is the area in $\mathrm{m}^{2}$, and $T$ is sampling duration in days.

\subsection{Methods}

Low- and high-frequency magnetic susceptibilities ( $\chi_{\text {lf }}$ and $\chi_{\mathrm{hf}}$, respectively) are measured using a MFK1-FA Kappabridge at frequencies of 976 and $15616 \mathrm{~Hz}$. Frequencydependent magnetic susceptibility $\left(\chi_{\mathrm{fd}}\right)$ is calculated as $\left(\chi_{\mathrm{lf}}-\chi_{\mathrm{hf}}\right) / \chi_{\mathrm{lf}} \times 100 \%$.

The temperature-dependent susceptibilities $(\chi-T)$ are measured in an argon atmosphere (the flow rate is $50 \mathrm{~mL} \mathrm{~min}^{-1}$ ) at a frequency of $976 \mathrm{~Hz}$ from room temperature up to $700^{\circ}$ and back to room temperature using a MFK1FA Kappabridge equipped with a CS-3 high-temperature furnace. The susceptibility of each sample is corrected for background (furnace tube correction) using the CUREVAL 8.0 program.

Hysteresis loops and first-order reversal curve (FORC) diagrams are measured by a vibrating sample magnetometer (VSM3900) to a maximum applied field of $1 T$. Hysteresis parameters, including the saturation magnetization $\left(M_{\mathrm{S}}\right)$, saturation remanent magnetization $\left(M_{\mathrm{rs}}\right)$, and coercivity $\left(B_{\mathrm{c}}\right)$, are obtained after subtracting the paramagnetic contribution. The remanence coercivity $\left(B_{\mathrm{cr}}\right)$ is obtained by demagnetizing samples from $+1 T$ back to $-1 T$. The hysteresis ratios $M_{\mathrm{rs}} / M_{\mathrm{S}}$ vs. $B_{\mathrm{cr}} / B_{\mathrm{c}}$ are used to construct a Day plot.

The FORC diagrams are measured with the averaging time of $200 \mathrm{~ms}$ and produced using FORCinel software (Harrison 

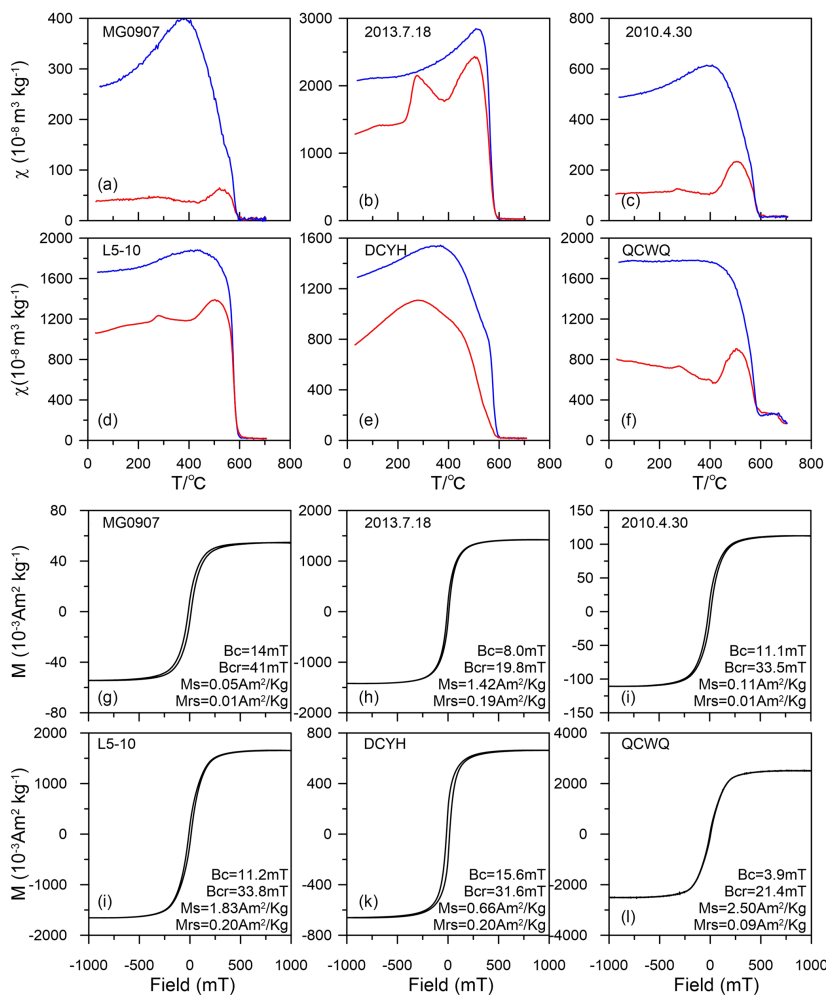

4000 QCWQ

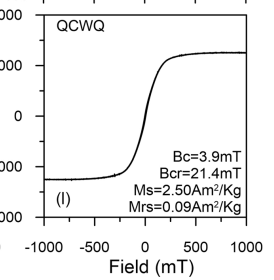

Figure 3. $\chi-T$ heating (red line) and cooling (blue line) curves (a-f) and magnetic hysteresis loops (g-l) of representative samples of natural surface sediments (MD0907), atmospheric dustfall (2013.7.18 and 2010.4.30), street dust (L5-10), and anthropogenic pollutants: fly ash (DCYH) and vehicle exhaust (QCWQ).

and Feinberg, 2008). A total of 18 samples are used for detailed iron oxide analyses, including 2 samples from each natural dust source with modal $\chi_{\text {If }}$ values, 4 dustfall samples and 2 street dust samples with high $\chi_{\mathrm{lf}}$ and low $\chi_{\mathrm{lf}}$, and 2 samples of vehicle exhaust and fly ash.

The magnetic components of these representative samples are separated from the bulk samples using a $1 T$ magnet sealed in a polyethylene bag. To confirm their mineral, morphological, and elemental characteristics, direct observations and measurements of the samples and their extracted magnetic particles are performed using a ZEISS EVO-18 scanning electron microscope (SEM) equipped with a Bruker XFlash 6130 energy dispersive spectroscope (EDS). Samples are mounted on the SEM stub with double-sided carbon tape and then coated with a thin gold film. The specified resolution of the SEM is $<5 \mathrm{~nm}$. The EDS detector is capable of detecting elements with atomic numbers $\geq 5$ and the detection sensitivity can reach $0.1 \mathrm{wt} \%$. Bulk samples and magnetic extracts are characterized by randomly selecting three to four fields of view and examining all the particles observed within the selected fields. All the measurements are made at the Institute of Earth Environment, Chinese Academy of Sciences, Xi'an.
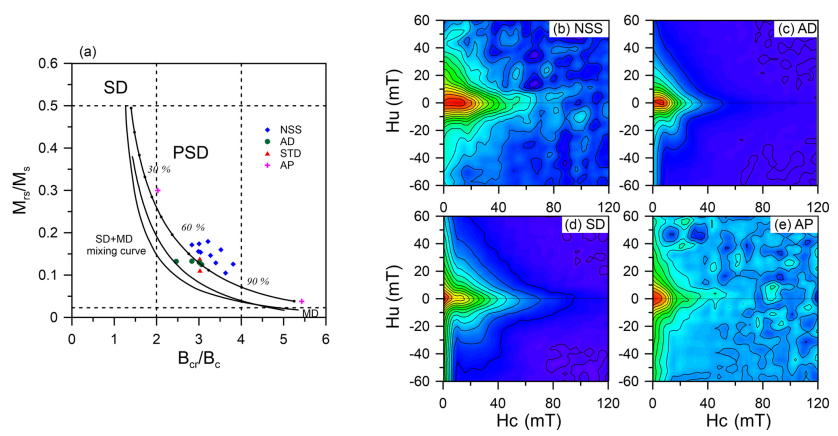

Figure 4. Day plot of the ratios $M_{\mathrm{rs}} / M_{\mathrm{S}}$ vs. $B_{\mathrm{cr}} / B_{\mathrm{c}}$ (a) and FORC diagrams (b-e) for representative samples from natural surface sediments (NSS), atmospheric dustfall (AD), street dust (STD), and anthropogenic pollutant (AP). Domain boundaries and the single-domain+multi-domain mixing line are according to Dunlop (2002b). Percentages in the Day plot represent the concentrations of multi-domain in the single-domain+multi-domain mixture.

\section{Results}

\subsection{Magnetic mineralogy}

$\chi-T$ is used to identify magnetic mineral composition. All the $\chi-T$ heating curves (Fig. 3a-f) are characterized by a major susceptibility decrease at $580^{\circ}$, i.e., the Curie temperature of magnetite, which identifies magnetite as the major contributor to $\chi$. All the samples are irreversible with cooling paths above heating trajectories due to the neoformation of magnetite (Jordanova et al., 2004; Kim et al., 2009). The $\chi-T$ heating curve of the vehicle exhaust displays a decreasing $\chi$ between 580 and $700^{\circ}$ (Fig. 3b), suggesting the presence of hematite.

All samples have similar slightly wasp-waisted hysteresis loops (Fig. 3g-1). Magnetic saturation is generally reached at a magnetic field of about $300 \mathrm{mT}$. This is a clear indication of the predominance of low-coercivity ferrimagnetic minerals in all samples.

\subsection{Hysteresis properties}

The Day plot and FORC diagram are powerful methods to identify the domain state distribution of magnetic materials (Day et al., 1977; Pike et al., 1999; Roberts et al., 2000; Dunlop, 2002a, b). All the samples agree well with singledomain + multi-domain admixture curves in the pseudosingle-domain range of the Day plot (Fig. 4a). The FORC diagrams for street dust (Fig. 4d) and anthropogenic pollutants (Fig. 4e) have divergent contours that are characteristic of multi-domain grains. The FORC diagram for natural surface sediments (Fig. 4b) seems to be characteristic of pseudosingle-domain and multi-domain behavior, whose outer contours display a divergent pattern and inner contours are somewhat less divergent. The FORC distributions of atmospheric dustfall (Fig. 4c) appear to have a mixed set of contours. 

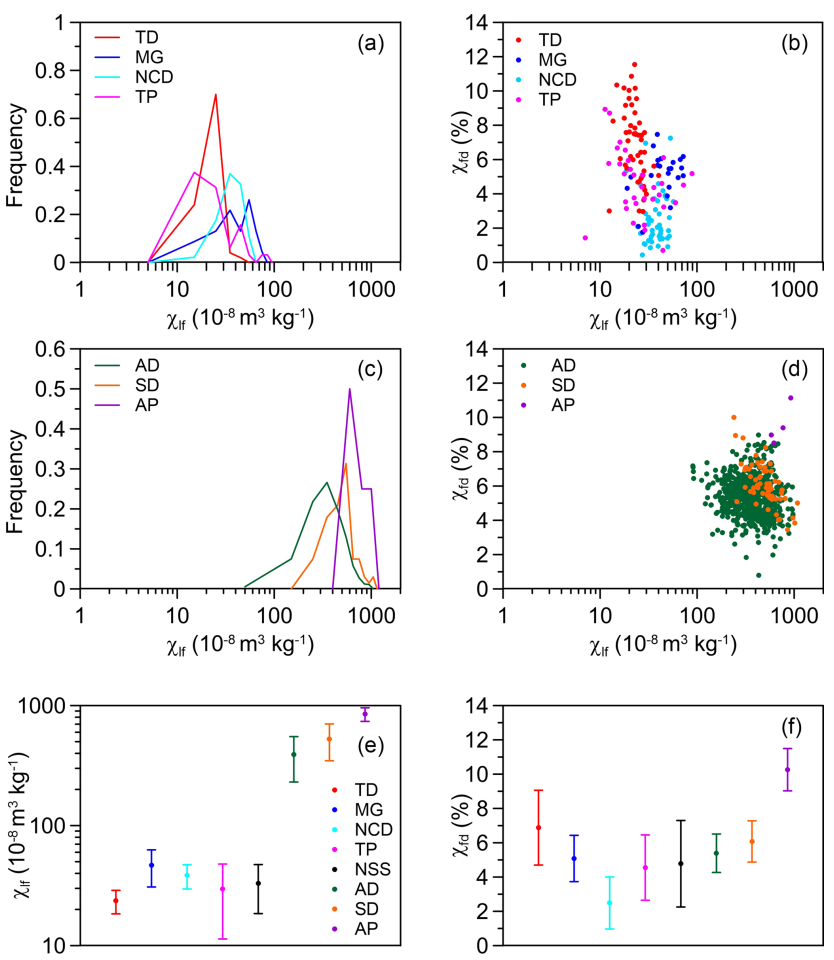

Figure 5. Frequency distribution of $\chi_{\mathrm{lf}}(\mathbf{a}, \mathbf{c})$, bivariate plots of $\chi_{\mathrm{lf}}$ versus $\chi_{\mathrm{fd}}(\mathbf{b}, \mathbf{d})$, and average values and standard deviations of $\chi_{\mathrm{lf}}$ and $\chi_{\mathrm{fd}}(\mathbf{e}, \mathbf{f})$ for NSS in each source and in urban dust aerosols, including AD, STD, and AP. Frequency distribution statistics of $\chi_{\text {lf }}$ for NSS, AD and STD, and AP are generated using intervals of $10 \times 10^{-8} \mathrm{~m}^{3} \mathrm{~kg}^{-1}, 100 \times 10^{-8} \mathrm{~m}^{3} \mathrm{~kg}^{-1}$, and $200 \times 10^{-8} \mathrm{~m}^{3} \mathrm{~kg}^{-1}$, respectively.

The outer contours have a divergent pattern that would be expected for multi-domain particles, while the inner distribution with closed contours represent single-domain grains.

\subsection{Spatial and temporal variations of $\chi$}

The magnetic susceptibilities of all bulk samples were measured to estimate concentrations of magnetic minerals, which are largely controlled by concentrations of ferromagnetic minerals (Dunlop and Özdemir, 1997; Evans and Heller, 2003; Liu et al., 2012). $\chi_{\mathrm{fd}}$ is sensitive to the superparamagnetic component. There are virtually no superparamagnetic grains when $\chi_{\mathrm{fd}}$ is $<2 \%$, while a mixture of superparamagnetic and coarser grains is indicated with $\chi_{\mathrm{fd}}$ in the range of $2-10 \%$ (Dearing, 1994; Dearing et al., 1996). The peaking of the $\chi_{\text {lf }}$ frequency distribution curve indicates the $\chi_{\mathrm{lf}}$ values are most distributed in this interval. Both $\chi_{\mathrm{lf}}$ and $\chi_{\mathrm{fd}}$ exhibit a distinctive distribution pattern in different sources.

$\chi_{\text {If }}$ values from the Taklimakan Desert and northern Chinese desert samples exhibit a unimodal distribution (Fig. 5a), and those from the Mongolian Gobi exhibit a bimodal distribution. However, $\chi_{\text {If }}$ values have a multimodal distribution in the Tibetan Plateau (Fig. 5a). Different distribution pat-

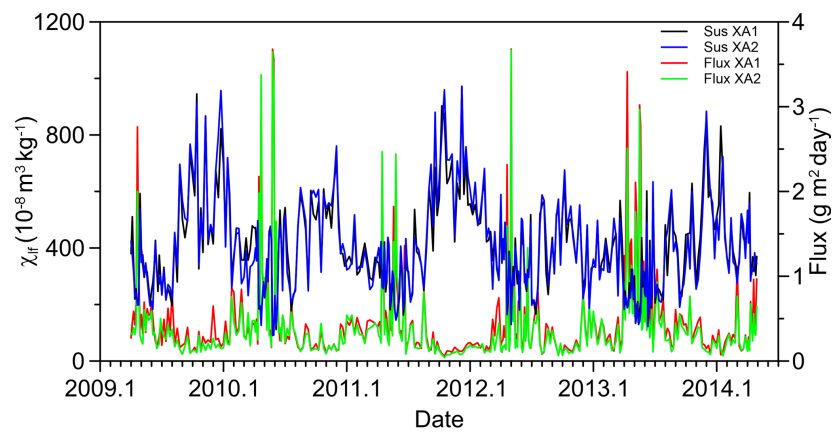

Figure 6. Time series of magnetic susceptibility and dust flux of atmospheric dustfall at XA1 and XA2 from 2009 to 2014.

terns and peak values of $\chi_{\text {If }}$ (Fig. 5a) indicate that the assemblage of magnetic minerals may differ in these four natural sources. Average $\chi_{\mathrm{If}}$ in individual sources shows a decreasing trend from the Mongolian Gobi, to northern Chinese deserts and the Tibetan Plateau, and then to the Taklimakan Desert (Fig. 5e). The mean values of $\chi_{\mathrm{fd}}$ in different natural sources show a decreasing trend of superparamagnetic components from the Taklimakan Desert to Mongolian Gobi and Tibetan Plateau, and then to northern Chinese deserts (Fig. 5f).

The frequency distributions of $\chi_{\text {lf }}$ for the street dust and atmospheric dustfall are both unimodal (Fig. 5c). The average $\chi_{\text {lf }}$ and $\chi_{\mathrm{fd}}$ values of the street dust are higher than those of the atmospheric dustfall and natural surface sediments (Fig. 5e). Low $\chi_{\text {If }}\left(<500 \times 10^{-8} \mathrm{~m}^{3} \mathrm{~kg}^{-1}\right)$ occurs in the Ecological District, Han Chang' an city ruins park, and Cultural District, while samples with intermediate $\chi_{\text {lf }}$ values $\left(500-800 \times 10^{-8} \mathrm{~m}^{3} \mathrm{~kg}^{-1}\right)$ are from the moderately developed Industrial District and the periphery of the Commercial District. In contrast, the central areas of the Industrial District and the Commercial District (particularly the area of high traffic density at the Bell Tower) are characterized by relatively high $\chi_{\text {If }}$ values $\left(>800 \times 10^{-8} \mathrm{~m}^{3} \mathrm{~kg}^{-1}\right) \cdot \chi_{\text {If }}$ of atmospheric dustfall from XA1 and XA2 exhibits significant and consistent seasonal variations (Fig. 6). The lowest (highest) $\chi_{\text {lf }}$ values correspond to the highest (lowest) dust flux in spring (autumn).

The representative anthropogenic pollutants, i.e., vehicle exhaust, fly ash, and nearby street dust at the Bell Tower and thermal power plant, have high $\chi_{\mathrm{If}}$ and $\chi_{\mathrm{fd}}$ (Fig. $5 \mathrm{c}, \mathrm{d}$ ). The $\chi_{\text {If }}$ and $\chi_{\mathrm{fd}}$ of vehicle exhaust and fly ash are higher than the mean values of other sources of dust (Fig. 5e, f).

\subsection{Morphology and mineralogy of the dust samples}

SEM provides morphology information based on gray-scale intensity. The elemental composition is determined by the EDS detector. In order to compare the morphology and mineralogy characteristics of different dust aerosols, more than 40 fields of views of the representative bulk samples were randomly obtained for various types of particles. The mor- 

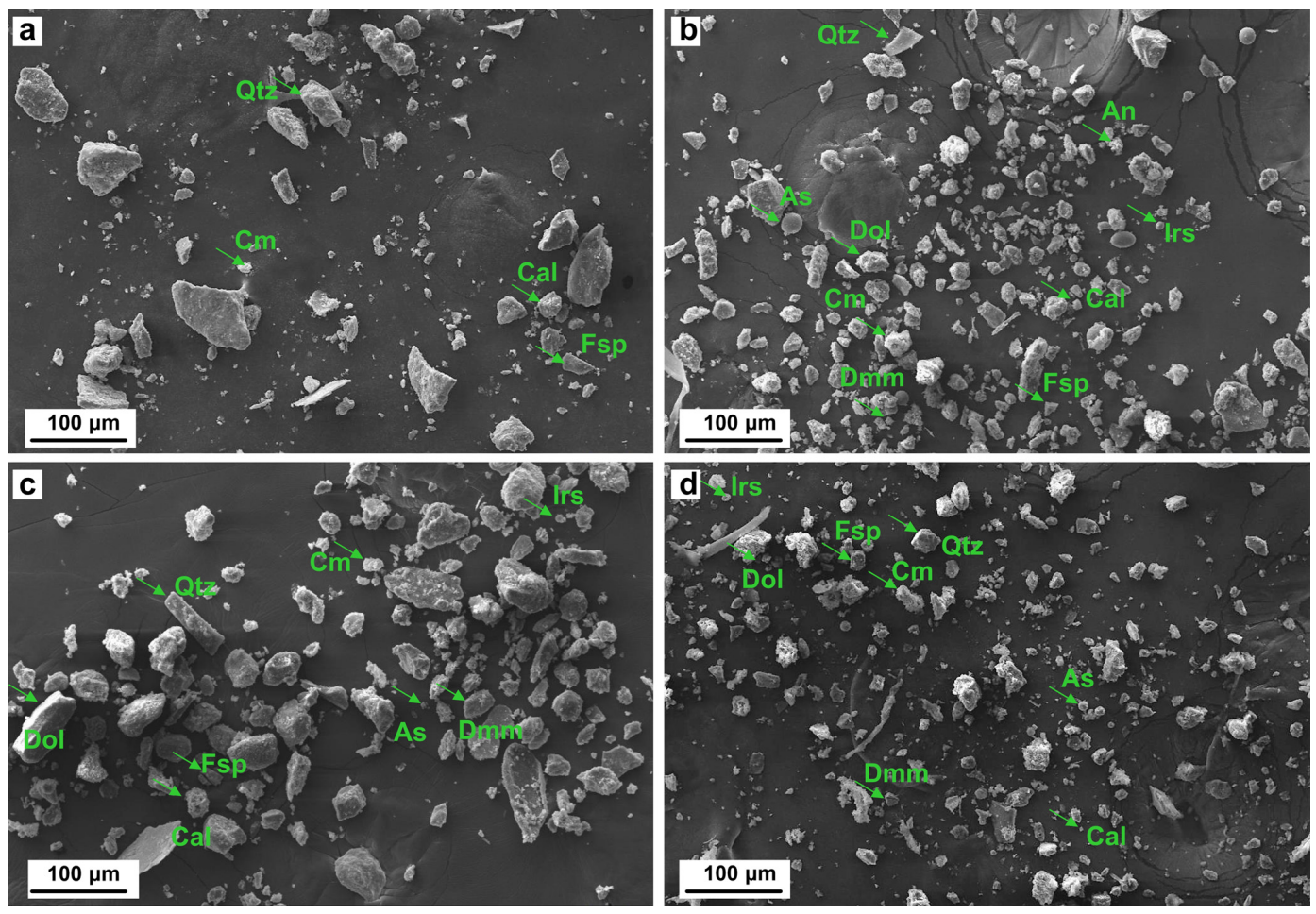

Figure 7. Morphology and mineralogy of representative samples of the natural surface sediments (a), street dust (b), and atmospheric dustfall with low $\chi_{\text {lf }}(\mathbf{c})$ and high $\chi_{\text {lf }}(\mathbf{d})$. Qtz - quartz, Fsp - feldspar, Cal - calcite, Dol - dolomite, Cm - clay minerals, Dmm - detrital magnetic mineral, Irs - iron-rich sphere, As - aluminosilicate sphere, An - anomalous particles with a porous and loose structure.

phologies and mineral compositions of the natural surface sediments, street dust, and atmospheric dustfall with low and high $\chi_{\text {If }}$ are illustrated in Fig. 7. The particles are typically angular and irregularly shaped in the surface sediments, with a broad size range (around 1-100 $\mu \mathrm{m}$ ). Based on the EDS analysis for each particle in the selected field, clay minerals, quartz, calcite, dolomite, and magnetic grains (Fig. 7a) were clearly identified (Welton, 1984).

The SEM-DES analysis shows that the morphology and constituents of the particles in the street dust are complex and heterogeneous. Three categories of particles can be morphologically differentiated, including irregular and aggregate mineral particles, spherical particles, and anomalous particles with porous and loose structures (Fig. 7b). Particles with irregular shapes are mainly minerals and commonly present in street dust samples. Compared to the natural surface sediments, the grain size of mineral particles in the street dust is finer and mostly ranges from $1-50 \mu \mathrm{m}$, with some up to $80 \mu \mathrm{m}$. Spherical particles are mainly amorphous siliconaluminum and iron-rich spheres, whose grain size varies mostly from $1-20 \mu \mathrm{m}$, with some up to $50 \mu \mathrm{m}$. There are a small number of anomalous particles with diameters of 10 $100 \mu \mathrm{m}$.

The morphology and mineral composition of atmospheric dustfall are similar to those of the street dust, except that atmospheric dustfall with low $\chi_{\text {lf }}$ has a higher content of ir- regularly shaped detrital minerals (Fig. 7c), while that with high $\chi_{\text {lf }}$ contains more spherical and anomalous particles (Fig. 7d).

\subsection{Elemental compositions of mineral particles}

Since the elemental compositions of mineral particles can be clearly distinguished using SEM-EDS analysis (Blanco et al., 2003; Kutchko and Kim, 2006), a street dust sample dominated by anthropogenic inputs with the highest $\chi_{\text {If }}$ was selected for EDS analysis. The results indicate that various mineral particles exhibit distinct chemical compositions (Fig. 8). The plate-like aggregates (labeled a) with high levels of $\mathrm{Si}$ and $\mathrm{Al}$ and low levels of $\mathrm{K}, \mathrm{Ca}, \mathrm{Mg}$, and $\mathrm{Fe}$ are clay minerals composed of crystalline sheet-structure silicates with a small particle size (Fig. 8a). The angular and sharp-edged particle (labeled b) with high $\mathrm{Si}$ and $\mathrm{O}$ is quartz (Fig. 8b). The angular particle consisting of $\mathrm{Si}, \mathrm{Al}$, and $\mathrm{K}$ is potassium feldspar (Fig. 8c). Particles with high levels of $\mathrm{Ca}$ and $\mathrm{Mg}$ are calcite (Fig. 8d) and dolomite (Fig. 8e).

The irregular particles (labeled $\mathrm{f}$ ) that are abundant in $\mathrm{Fe}$ are identified as magnetic grains (Fig. 8f), although some of the particles show low levels of crustal elements, including $\mathrm{Si}, \mathrm{Al}, \mathrm{Ca}$, and $\mathrm{K}$. Two types of spheres were observed. One (labeled g) is an amorphous aluminosilicate particle (Fig. 8g) with predominant $\mathrm{Si}$ and $\mathrm{Al}$ and lesser amounts of $\mathrm{K}, \mathrm{Mg}, \mathrm{Na}$, 

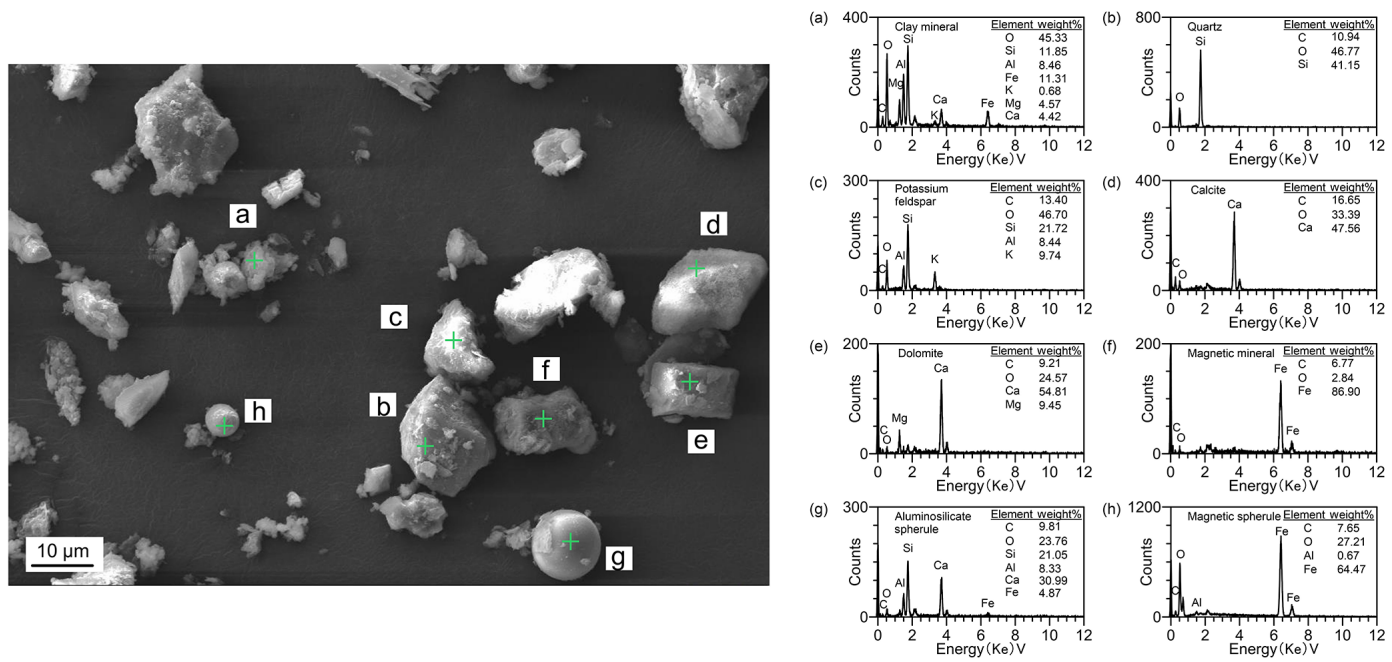

Figure 8. SEM photograph and elemental spectra for a typical sample of street dust. In the subplots, the green plus symbols denote the locations of the beam used in the EDS analysis.
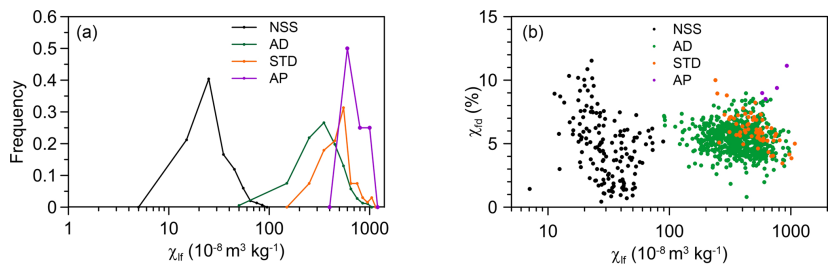

Figure 9. Frequency distributions of $\chi_{\text {lf }}$ (a) and bivariate plots of $\chi_{\text {lf versus }} \chi_{\mathrm{fd}}(\mathbf{b})$ of NSS, STD, AD, and AP.

and Ti. The other (labeled h) is an iron-rich sphere (Fig. 8h), which is mainly composed of Fe. These particles exhibit various surface textures. In addition, almost all particles contain $\mathrm{O}$ and $\mathrm{C}$.

\section{Discussion}

\subsection{Contributions of local anthropogenic sources estimated by dust flux and $\chi_{\text {If }}$}

On the bivariate plot of $\chi_{\mathrm{lf}}$ vs. $\chi_{\mathrm{fd}}$, atmospheric dustfall is intermediate between the surface sediments and street dust (Fig. 9b), implying that atmospheric dustfall is a mixture of distal natural dust and local anthropogenic dust, but much closer to the latter. The local anthropogenic contribution (LC) is mainly derived from local stable and sustained pollutant sources, including vehicle emissions and fly ash. Considering that natural dust comes primarily from natural dust sources with a minor local soil contribution (Wang et al., 2004; Ginoux et al., 2012), we attribute the natural contribution entirely to the distal natural dust.

The dust flux background can be taken as the average input from the end-member of LC. The time-dependent back- ground estimation was calculated using

$x(i)_{\mathrm{bg}}=\operatorname{MED}_{j=i-k}^{j=i+k}(x(j))$,

where $i=k+1, \ldots, n-k, x(i)_{\mathrm{bg}}$ is the background of $x(i)$ at time $t(i) . \operatorname{MED}_{j=i-k}^{j=i+k}(x(j))$ is the running median with window points of $2 k+1(k \leq(n-1) / 2)$ (Härdle and Steiger, 1995); cross-validation can be used to choose $k$. We used two such criteria: the median criterion (Zheng and Yan, 1988) and $L_{1}$ norm (Marron, 1986; Dodge, 2012).

$$
\begin{aligned}
\mathrm{CV}_{\mathrm{m}}(k) & =\operatorname{median}\left\{\left|x(i)-\operatorname{MED}_{j=i-k, j \neq i}^{j=i+k}(x(j))\right|\right\} \\
\mathrm{CV}_{1}(k) & =\left[\sum_{i=1}^{n}\left|x(i)-\operatorname{MED}_{j=i-k, j \neq i}^{j=i+k}(x(j))\right|\right] / n
\end{aligned}
$$

$\operatorname{MED}_{j=i-k, j \neq i}^{j=i+k}(x(j))$ is the delete-one background estimate. The cross-validation functions are to measure the average performance of the delete-one estimate to predict the observation $x(i)$. Optimal $k$ values should minimize $\mathrm{CV}_{\mathrm{m}}(k)$ or $\mathrm{CV}_{1}(k)$ (Mudelsee, 2006).

Through the cross-validation calculation on the dust flux series of atmospheric dustfall, we find that the crossvalidated number of window width (Eq. 3 ) is $k=19$. On this basis, we calculate the monthly LC using the ratio of monthly background and total dust flux as

$\mathrm{LC}_{\text {flux }}=x(j)_{\mathrm{bg}} / \mathrm{DF} \times 100 \%$,

where $\mathrm{LC}_{\text {flux }}$ is the percentage of the monthly local anthropogenic contribution estimated by dust flux (Fig. 10a). Note that when the background is larger than the dust flux, LC is taken to be $100 \%$.

$M_{\mathrm{S}}$ values of representative samples (Fig. 3h-m) are measured to identify the concentration of ferrimagnetic minerals. 

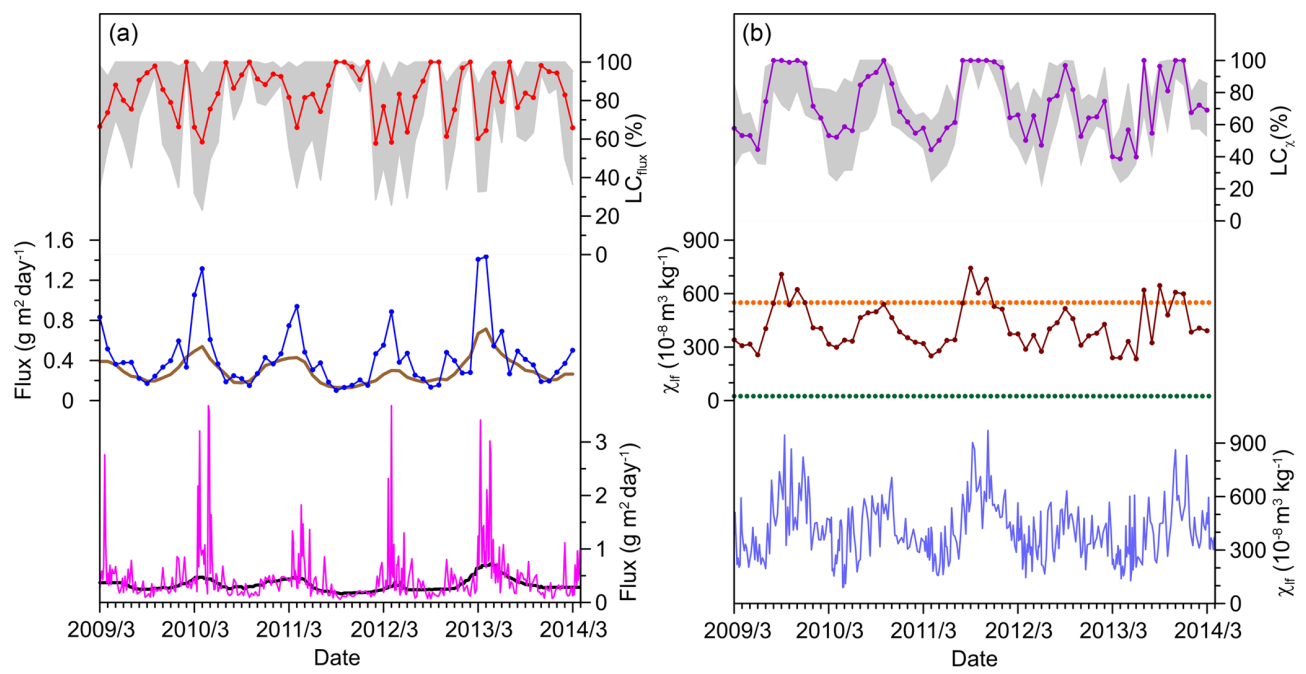

Figure 10. The estimated local contributions by dust flux (a) and $\chi_{\text {lf }}$ (b). From bottom to top: (a) dust flux (pink) and background estimate by the running median with a cross-validated number of window points $(k=19)$ (black), monthly averaged dust flux (blue) and background (brown), average monthly local contribution (red) estimated by dust flux at XA1, and the uncertainty bounds calculated by standard deviation (gray area). (b) $\chi_{\text {lf }}$ values (light blue), averaged $\chi_{\text {lf }}$ values of natural distant dust (green dotted lines), monthly averaged $\chi_{\text {lf }}$ values (dark red), averaged $\chi_{\mathrm{lf}}$ values of local street dust (orange dotted lines), monthly local contribution (violet) estimate by $\chi_{\mathrm{lf}}$ at XA1, and the uncertainty boundaries calculated by standard deviation (gray area).

We find that the averaged values of $M_{\mathrm{S}}$ in different sources show a rising trend from the natural surface sediments $\left(0.04 \mathrm{Am}^{2} \mathrm{~kg}^{-1}\right)$ to atmospheric dustfall $\left(0.81 \mathrm{Am}^{2} \mathrm{~kg}^{-1}\right)$ and street dust $\left(1.03 \mathrm{Am}^{2} \mathrm{~kg}^{-1}\right)$, and then to anthropogenic pollutants $\left(1.58 \mathrm{Am}^{2} \mathrm{~kg}^{-1}\right)$, which correspond to the characteristics of averaged $\chi_{\text {If }}$ in different sources. This indicates that the high $\chi_{\text {lf }}$ of urban dust is caused by ferrimagnetic minerals from a local anthropogenic source. In consequence, the LC contribution could also be estimated by the peak values of $\chi_{\text {If }}$ frequency distribution, with 20 $30 \times 10^{-8} \mathrm{~m}^{3} \mathrm{~kg}^{-1}$ in the distant natural surface sediments and $500-600 \times 10^{-8} \mathrm{~m}^{3} \mathrm{~kg}^{-1}$ in local street dust (Fig. 9a). On this basis, we calculate the average LC using the following equation:

$\mathrm{LC}_{\chi}=\left(\chi_{\mathrm{m}}-25\right) /(550-25) \times 100 \%$,

where $\mathrm{LC}_{\chi}$ is the percentage of the monthly local contribution estimated by $\chi_{\text {lf }}$ (Fig. 10b), and $\chi_{\mathrm{m}}$ is the monthly average $\chi_{\text {If }}$ value in $10^{-8} \mathrm{~m}^{3} \mathrm{~kg}^{-1} .25 \times 10^{-8}$ and $550 \times$ $10^{-8} \mathrm{~m}^{3} \mathrm{~kg}^{-1}$ are the average $\chi_{\text {If }}$ values of surface sediments from source regions and local street dust, respectively. Note that when $\chi_{\mathrm{m}}$ is larger than the average $\chi_{\text {lf }}$ of the street dust, $\mathrm{LC}$ is taken to be $100 \%$.

The $\mathrm{LC}_{\text {flux }}$ and $\mathrm{LC}_{\chi}$ values have the same trend and show a distinctive seasonal pattern (Fig. 10a, b), with a maximum in autumn $(92.4 \%, 92.3 \%)$, followed by winter $(90.8 \%, 74.7 \%)$, summer $(83.5 \%, 71 \%)$, and spring $(73.0 \%, 53.1 \%)$. Both the $\mathrm{LC}_{\text {flux }}$ and $\mathrm{LC}_{\chi}$ are the lowest in spring, implying that distant natural dust input makes a great contribution to atmospheric dustfall during this period.
The LC variation exhibits a similar seasonal pattern to $\chi_{\mathrm{lf}}$, but an opposite trend to that of dust flux (Fig. 10a, b). This suggests that the major sources of atmospheric dustfall varied seasonally between the distant natural sources in spring and local anthropogenic sources in other seasons. In spring, dust is emitted from the natural sources by strong winds, and after long-range transport it contributes to the elevated dust flux in Xi' an and decreases the LC in atmospheric dustfall. However, from summer to winter, dust input from local anthropogenic sources is low and stable as indicated by the high LC.

\subsection{Magnetic characteristics of anthropogenic particles}

SEM-EDS analysis shows that the extracted magnetic particles from the street dust and atmospheric dustfall can be divided into detrital and anthropogenic types (Fig. 11ac). Detrital particles are angular and characterized by relatively smooth surfaces, with $\mathrm{Fe}$ and $\mathrm{O}$ as the major elements and minor amounts of Ti (Fig. 11d), indicating the presence of magnetite, hematite, and titanomagnetite (Maher and Thompson, 1991; Liu et al., 2015). Anthropogenic particles include angular particles with coarse surface textures, spherules, aggregates, and porous particles with complex internal structures. The major elements identified in these particles are $\mathrm{Fe}$ and $\mathrm{O}$, which indicate the occurrence of magnetite or hematite, consistent with previously identified anthropogenic magnetic particles (Kim et al., 2007; Koukouzas et al., 2007; Maher, 2009). Minor concentrations of S, Zn, $\mathrm{Cu}$, and $\mathrm{Cr}$ were also observed in this type of particle, which is typically attributed to anthropogenic activities (Fig. 11d). 


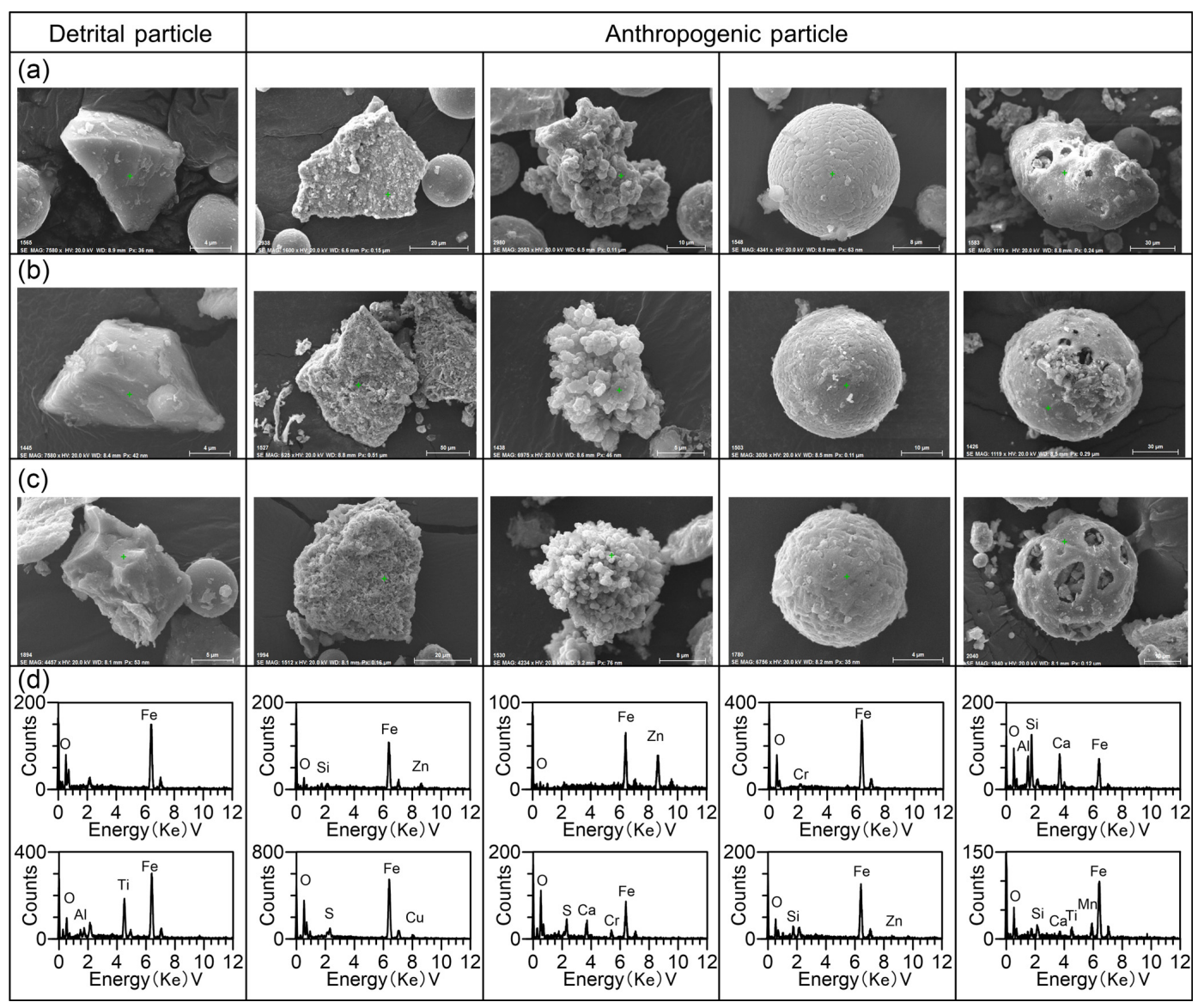

Figure 11. SEM images and typical elemental spectra (d) of magnetic extracts from street dust and (a) atmospheric dustfall with high $\chi_{\mathrm{lf}}$ (b) and low $\chi_{\text {lf }}$ (c). From left to right, the particle morphologies represent detrital particles with relatively smooth surfaces from natural source regions, anthropogenic particles with angular shapes and coarse surface textures, aggregates, spherules, and porous features.

The relatively weaker signal intensity of $\mathrm{Fe}$ in the EDS spectra of porous particles indicates a much lower Fe concentration (maximum less than $10 \%$ ), while their concentrations of $\mathrm{Si}, \mathrm{Al}, \mathrm{Ca}, \mathrm{Ti}$, and $\mathrm{Mn}$ are higher.

The morphology and concentration of magnetic materials in urban dust aerosols varied with sampling sites and over time. Among more than 20 images of analyzed magnetic extracts from urban dust samples, angular particles with coarse surface textures were the most frequently observed (>50\%, some up to $80 \%$ ), with a wide range of grain size $(1-100 \mu \mathrm{m})$. Spherules were also commonly observed in all samples, ranging from 10-40\%, mainly with diameters from 10-30 $\mu \mathrm{m}$. Aggregates with diameters of 5-30 $\mu \mathrm{m}$ account for less than $10 \%$. Detrital particles characterized by smooth surfaces range from 1-5\% and have small diameters (1$20 \mu \mathrm{m})$. Porous particles are the least observed magnetic particles $(<1 \%)$ with diameters of $30-120 \mu \mathrm{m}$. The SEM-EDS data show that the morphology and concentration of magnetic particulates in atmospheric dustfall with high $\chi_{\text {lf }}$ values are similar to those of the street dust, whereas atmospheric dustfall with low $\chi_{\text {lf }}$ contains more angular-subangular magnetic particles of detrital origin.

\subsection{Potential sources of anthropogenic magnetic particles}

Anthropogenic magnetic particles in the urban environment are mainly derived from the combustion of fossil fuels (Flanders, 1994; Matzka and Maher, 1999; Muxworthy et al., 2001), vehicle emissions (Harrison et al., 1997b; Moreno et al., 2003; Diapouli et al., 2008; Pant and Harrison, 2013; Maher et al., 2013), and industrial activities (Hanesch et al., 2003; Desenfant et al., 2004). To clarify potential sources, microscopic and elemental investigations of magnetic extracts from anthropogenic pollutants were performed using SEM-EDS. Compared with the magnetic particles in atmospheric dustfall (Fig. 12a-d), those from vehicle exhaust consist of only three types of particles, including angular particles with coarse surface textures, spherules, and aggregates (Fig. 12e-g), while all magnetic particle types in dustfall samples were identified in fly ash (Fig. 12h-k). The EDS analysis showed that the major elements of the same three 


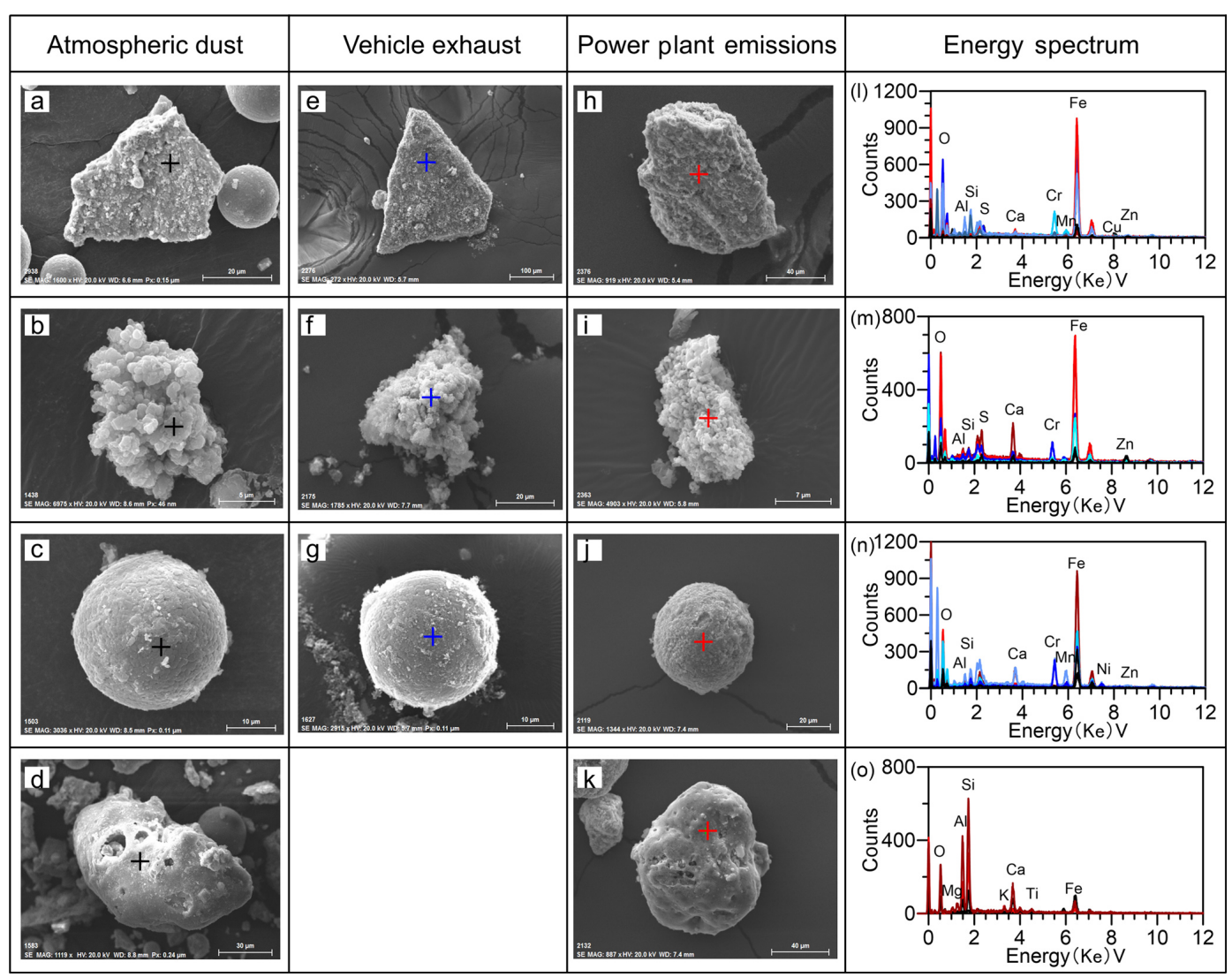

Figure 12. SEM images and elemental spectra of magnetic extracts from atmospheric dustfall (a-d), vehicle exhaust (e-g), and fly ash (h-k). Black lines are elemental spectra of atmospheric dustfall. Blue and red lines are elemental spectra for vehicle exhaust and fly ash.

types of magnetic particles in vehicle exhaust and fly ash are $\mathrm{Fe}$ and $\mathrm{O}$, consistent with elemental features of those in atmospheric dustfall (Fig. 12l-n). This suggests that vehicle exhaust and fly ash are the main pollutant sources in dustfall. However, there are some differences in the compositions of the minor elements in the three types of particles between vehicle exhaust and fly ash. Angular particles with coarse surface textures from vehicle exhaust contain more $\mathrm{S}, \mathrm{Cr}, \mathrm{Cu}$, $\mathrm{Zn}$, and $\mathrm{Mn}$, while those from fly ash have more $\mathrm{Ca}$ and $\mathrm{Mn}$. Aggregates consist of more $\mathrm{Cr}, \mathrm{Zn}$, and $\mathrm{S}$ in vehicle exhaust, whereas $\mathrm{Ca}$ and $\mathrm{S}$ are enriched in fly ash. Spherules from vehicle exhaust contain higher amounts of heavy metals $(\mathrm{Cr}$, $\mathrm{Ni}, \mathrm{Mn}$, and $\mathrm{Zn}$ ), while those from fly ash have higher $\mathrm{Ca}$ and Mn. Coarse-grained porous magnetic particles were only observed in fly ash, which are relatively low in Fe and high in crustal elements (e.g., $\mathrm{Si}, \mathrm{Al}, \mathrm{K}, \mathrm{Ca}, \mathrm{Mg}$, and Ti).

The EDS elemental data clearly indicate that the magnetic particles from vehicle exhaust contain higher concentrations of a greater range of elements from anthropogenic activities ( $\mathrm{S}, \mathrm{Cr}, \mathrm{Cu}, \mathrm{Zn}, \mathrm{Ni}$, and $\mathrm{Mn}$ ) than those from fly ash, whose EDS spectra show a substantial peak of $\mathrm{Ca}$. The $\chi_{\text {If }}\left(925.7 \times 10^{-8} \mathrm{~m}^{3} \mathrm{~kg}^{-1}\right)$ and $M_{\mathrm{S}}\left(2.5 \mathrm{Am}^{2} \mathrm{Kg}^{-1}\right)$ values of vehicle exhaust are significantly higher than those of fly ash $\left(769.9 \times 10^{-8} \mathrm{~m}^{3} \mathrm{~kg}^{-1}\right.$ and $\left.0.66 \mathrm{Am}^{2} \mathrm{Kg}^{-1}\right)$, indicating a higher content of ferrimagnetic contaminants. In summary, the magnetic particles emitted by vehicle exhaust and thermal power plants can be distinguished by a combination of morphological and elemental characteristics, which indicates that SEM-EDS can be used to trace the sources of anthropogenic pollutants in Xi'an.

\section{Conclusions}

By comparing the magnetic properties of surface sediments in natural dust sources in East Asia and various urban dust samples in Xi' an, we found that distal natural dust and local anthropogenic dust have different magnetic, morphological, and elemental characteristics. We take natural surface sediments as representative of distal natural dust, with background atmospheric dustfall and polluted street dust as representative of local anthropogenic dust. Based on this endmember configuration, the relative contributions of local anthropogenic sources to urban atmospheric dustfall can be quantitatively estimated.

The results show that local anthropogenic contribution decreases in spring and increases in other seasons. Local anthropogenic contribution variation exhibits a similar seasonal 
pattern to $\chi_{\mathrm{lf}}$, but an opposite trend to that of dust flux with a maximum in spring. This means that a great amount of distant natural dust input with less magnetic content makes a great contribution to atmospheric dustfall in spring, which results in minimum $\chi_{1 \mathrm{f}}$ and anthropogenic contributions during this period. Hence, the local contribution is reduced as a result of increasing natural dust flux.

SEM-EDS analysis of urban dust indicates that magnetic particles produced by anthropogenic activities have distinct morphological and elemental characteristics. The anthropogenic particles exhibit angular, spherical, aggregate, and porous shapes and contain distinctive marker elements such as $\mathrm{S}, \mathrm{Cr}, \mathrm{Cu}, \mathrm{Zn}, \mathrm{Ni}, \mathrm{Mn}$, and $\mathrm{Ca}$. The porous particles are likely derived from the thermal power plant, while others may be attributed to both vehicle exhaust and the thermal power plant. Our results suggest that magnetic signatures combined with morphological and elemental compositions can be used to quantitatively estimate local and anthropogenic contributions to urban dust aerosols.

Data availability. All relevant data are accessible for the public on the website http://paleo-data.ieecas.cn (last access: 10 January 2019; China IEECAS, 2009). One can also contact the author for access.

Author contributions. HL and YS designed the study and collected urban dust aerosols. YY, LL, HC, and XL performed the fieldwork. HL and YY contributed to dust flux analysis. HL and HC conducted the morphology and mineralogy experiments. XQ analyzed the magnetic data. All authors contributed to discussion, interpretation of the results, and writing the paper.

Competing interests. The authors declare that they have no conflict of interest.

Acknowledgements. We thank Min Zhao and Hua Wang for the help in sample collection. We are also grateful for the help of Maojie Yang with SEM-EDS measurements and Jan Bloemendal with language polishing. This work was supported by the National Key Research and Development Program of China (2016YFA0601902) and the Open Foundation of State Key Laboratory of Loess and Quaternary Geology (SKLLQG1631).

Edited by: Patrick Chuang

Reviewed by: two anonymous referees

\section{References}

Adachi, K. and Tainosho,Y.: Characterization of heavy metal particles embedded in tire dust, Environ. Int., 30, 1009-1017, https://doi.org/10.1016/j.envint.2004.04.004, 2004.
Baddock, M. C., Strong C. L., Murray, P. S., and McTainsh, G. H.: Aeolian dust as a transport hazard, Atmos. Environ., 71, 7-14, https://doi.org/10.1016/j.atmosenv.2013.01.042, 2013.

Blaha, U., Sapkota, B., Appel, E., Stanjek, H., and Rösler, W.: Micro-scale grain-size analysis and magnetic properties of coalfired power plant fly ash and its relevance for environmental magnetic pollution studies, Atmos. Environ., 42, 8389-8370, https://doi.org/10.1016/j.atmosenv.2008.07.051, 2008a.

Blaha, U., Appel, E., and Stanjek, H.: Determination of anthropogenic boundary depth in industrially polluted soil and semi-quantification of heavy metal loads using magnetic susceptibility, Environ. Pollut., 156, 278-289, https://doi.org/10.1016/j.envpol.2008.02.013, 2008b.

Blanco, A., Dee Tomasi, F., Filippo, E., Manno, D., Perrone, M. R., Serra, A., Tafuro, A. M., and Tepore, A.: Characterization of African dust over southern Italy, Atmos. Chem. Phys., 3, 21472159, https://doi.org/10.5194/acp-3-2147-2003, 2003.

Bourliva, A., Papadopoulou, L., and Aidona, E.: Study of road dust magnetic phases as the main carrier of potentially harmful trace elements, Sci. Total Environ., 553, 380-391, https://doi.org/10.1016/j.scitotenv.2016.02.149, 2016.

Brunekreef, B. and Holgate, S. T.: Air pollution and health, Lancet., 360, 1233-1242, https://doi.org/10.1016/S0140-6736(02)112748, 2002

Chen, Y. S., Sheen, P. C., Chen, E. R., Liu Y. K., Wu, T. N., and Yang, C. Y.: Effects of Asian dust storm events on daily mortality in Taipei, Taiwan, Environ. Res., 95, 151-155, https://doi.org/10.1016/j.envres.2003.08.008, 2004.

China IEECAS (Institute of Earth Environment, Chinese Academy of Sciences, China): East Asian Paleoenvironmental Science Database, available at: http://paleo-data.ieecas.cn/ (last access: 10 January 2019), 2009

Chow, J. C., Engerlbrecht, J. P., Freeman, N. C. G., Hashim, J. H., Jantunen, M., Michaud, J-P., de Tejada, S. S., Watson, J. G., Wei, F., Wilson, W. E., Yasuno, M., and Zhu, T.: Chapter one: exposure measurements, Chemosphere., 49, 873-901, https://doi.org/10.1016/S0045-6535(02)00233-3, 2002.

Day, R., Fuller, M., and Schmidt, V. A.: Hysteresis properties of titanomagnetite: Grain-size and compositional dependence, Phys. Earth Planet In., 13, 260-267, https://doi.org/10.1016/00319201(77)90108-X, 1977.

Dearing, J. A.: Environmental Magnetic Susceptibility, Using the Bartington MS2 system, Chi. Publ., Kenilworth, 1994.

Dearing, J. A., Hay, K. L., Baban, S. M. J., Huddleston, A. S., Wellington, E. M. H., and Loveland, P. J.: Magnetic susceptibility of soil: an evaluation of conflicting theories using a national data set, Geophys. J. Int., 127, 728-734, https://doi.org/10.1111/j.1365-246X.1996.tb04051.x, 1996.

de Miguel, E., Llamas, J. F., Chacón, E., Berg, T., Larssen, S., Røyset, O., and Vadset, M.: Origin and patterns of distribution of trace elements in street dust: unleaded petrol and urban lead, Atmos. Environ., 31, 2733-2740, https://doi.org/10.1016/S13522310(97)00101-5, 1997.

Desenfant, F., Petrovský, E., and Rochette, P.: Magnetic Signature of Industrial Pollution of Stream Sediments and Correlation with Heavy Metals: Case Study from South France, Water Air Soil Poll., 152, 297-312, https://doi.org/10.1023/B:WATE.0000015356.88243.f0, 2004. 
Diapouli, E., Chaloulakou, A., Mihalopoulos, N., and Spyrellis, N.: Indoor and outdoor PM mass and number concentrations at schools in the Athens area, Environ. Monit. Assess., 136, 13-20, https://doi.org/10.1007/s10661-007-9724-0, 2008.

Dodge, Y.: Statistical data analysis based on the L1-Norm and related methods, Birkhäuser, Neuchatel, 2012.

Dunlop, D. J.: Theory and application of the Day plot (Mrs/Ms versus $\mathrm{Hcr} / \mathrm{Hc}$ ) 1. Theoretical curves and tests using titanomagnetite data, J. Geophys. Res., 107, 2076, https://doi.org/10.1029/2001JB000486, 2002a.

Dunlop, D. J.: Theory and application of the Day plot (Mrs/Ms versus $\mathrm{Hcr} / \mathrm{Hc}$ ) 2. Application to data for rocks,sediments, and soils, J. Geophys. Res., 107, 2057, https://doi.org/10.1029/2001JB000487, 2002b.

Dunlop, D. J. and Özdemir, Ö.: Rock magnetism: fundamentals and Frontiers, Cambridge University Press, UK, 1997.

Elser, M., Huang, R.-J., Wolf, R., Slowik, J. G., Wang, Q., Canonaco, F., Li, G., Bozzetti, C., Daellenbach, K. R., Huang, Y., Zhang, R., Li, Z., Cao, J., Baltensperger, U., El-Haddad, I., and Prévôt, A. S. H.: New insights into $\mathrm{PM}_{2.5}$ chemical composition and sources in two major cities in China during extreme haze events using aerosol mass spectrometry, Atmos. Chem. Phys., 16, 3207-3225, https://doi.org/10.5194/acp-16-3207-2016, 2016.

Evans, M. E. and Heller, F.: Environmental magnetism: principles and applications of enviromagnetics, Volume 86, Academic Press, San Diego, 2003.

Feng, S. P., Liu, H. C., Zhang, N. N., Lin, H., Du, X. L., and Liu, Y. L.: Contamination assessment of copper, lead, zinc and chromium in dust fall of Jinan, NE China, Environ. Earth Sci., 66, 1881-1886, https://doi.org/10.1007/s12665-011-1412-2, 2012.

Finlayson-Pitts, B. J., Wingen, L. M., Sumner, A. L., Syomin, D., and Ramazan, K. A.: The heterogeneous hydrolysis of $\mathrm{NO}_{2}$ in laboratory systems and in outdoor and indoor atmospheres: An integrated mechanism, Phys. Chem. Chem. Phys., 5, 223-242, https://doi.org/10.1039/B208564j, 2003.

Flanders, P. J.: Collection, measurement, analysis of airborne magnetic particulates from pollution in the environment, J. Appl. Phys., 75, 5931-5936, https://doi.org/10.1063/1.355518, 1994.

Fleming, Z. L., Monks, P. S., and Manning, A. J.: Review: Untangling the influence of air-mass history in interpreting observed atmospheric composition, Atmos. Res., 104-015, 1-39, https://doi.org/10.1016/j.atmosres.2011.09.009, 2012.

Ginoux, P., Prospero, J. M., Torres, O., and Chin, M.: Longterm simulation of global dust distribution with the GOCART model: correlation with North Atlantic Oscillation, Environ. Model Softw., 19, 113-128, https://doi.org/10.1016/S13648152(03)00114-2, 2004.

Ginoux, P., Prospero, J. M., Gill,T. E., Hsu, N. C., and Zhao, M.: Global-scale attribution of anthropogenic and natural dust sources and their emission rates based on MODIS Deep Blue aerosol products, Rev. Geophys., 50, RG3005, https://doi.org/10.1029/2012RG000388, 2012.

Gomez, E. T., Sanfeliu, T., Jordan, M. M., Rius, J., and de la Fuente, C.: Geochemical characteristics of particulate matter in the atmosphere surrounding a ceramic industrialized area, Environ. Geol., 45, 536-543, https://doi.org/10.1007/S00254-003-0908-9, 2004.

Gorden, G. E.: Receptor models, Environ. Sci. Technol., 22, 11321142, https://doi.org/10.1021/es00175a002, 1988.
Gupta, A. K., Karar, K., and Srivastava, A.: Chemical mass balance source apportionment of PM10 and TSP in residential and industrial sites of an urban region of Kolkata, India, J. Hazard. Mater., 142, 279-287, https://doi.org/10.1016/j.jhazmat.2006.08.013, 2007.

Härdle, W. and Steiger, W.: Algorithm AS 296: Optimal median smoothing, Appl. Stat-J. Roy. St. C., 44, 258-264, 1995.

Hanesch, M., Scholger, R., and Rey, D.: Mapping dust distribution around an industrial site by measuring magnetic parameters of tree leaves, Atmos. Environ., 37, 5125-5133, https://doi.org/10.1016/j.atmosenv.2003.07.013, 2003.

Hanisch, F. and Crowley, J. N.: Heterogeneous reactivity of gaseous nitric acid on $\mathrm{Al}_{2} \mathrm{O}_{3}, \mathrm{CaCO}_{3}$, and atmospheric dust samples: A Knudsen cell study, J. Phys. Chem. A., 105, 3096-3106, https://doi.org/10.1021/jp001254+, 2001.

Hansard, R., Maher, B. A., and Kinnersley, R.: Biomagnetic monitoring of industry-derived particulate pollution, Environ. Pollut., 159, 1673-1681, https://doi.org/10.1016/j.envpol.2011.02.039, 2011.

Hansard, R., Maher, B. A., and Kinnersley, R. P.: Rapid Magnetic Biomonitoring and Differentiation of Atmospheric Particulate Pollutants at the Roadside and around Two Major Industrial Sites in the U.K., Environ. Sci. Technol., 46, 4403-4410, https://doi.org/10.1021/es203275r, 2012.

Harrison, R. J. and Feinberg, J. M.: FORCinel: An improved algorithm for calculating first-order reversal curve distributions using locally weighted regression smoothing, Geochem. Geophy. Geosy., 9, Q05016, https://doi.org/10.1029/2008GC001987, 2008.

Harrison, R. M., Smith, D. J. T., Piou, C. A., and Castro, L. M.: Comparative receptor modellion study of airborne particulate pollutants in Birminghan (United Kingdom), Coimbra (Portugal) and Lahore (Pakistan), Atmos. Environ., 131, 3309-3321, https://doi.org/10.1016/S1352-2310(97)00152-0, 1997a.

Harrison, R. M., Deacon, A. R., Jones, M. R., and Appleby, R. S.: Sources and processes affecting concentrations of $\mathrm{PM}_{10}$ and $\mathrm{PM}_{2.5}$ particulate matter in Birmingham (U. K.), Atmos. Environ., 31, 4103-4117, https://doi.org/10.1016/S13522310(97)00296-3, 1997b.

Hoffmann, V., Knab, M., and Appel, E.: Magnetic susceptibility mapping of roadside pollution, J. Geochem. Explor., 66, 313326, https://doi.org/10.1016/S0375-6742(99)00014-X, 1999.

Huang, R. J., Zhang, Y., Bozzetti, C., Ho, K. F., Cao, J. J., Han, Y. M., Daellenbach, K. R., Slowik, J. G., Platt, S. M., Canonaco, F., Zotter, P., Wolf, R., Pieber, S. M., Bruns, E. A., Crippa, M., Ciarelli, G., Piazzalunga, A., Schwikowski, M., Abbaszade, G., Schnelle-Kreis, J., Zimmermann, R., An, Z. S., Szidat, S., Baltensperger, U., Haddad, I. E., and Prevot, A. S. H.: High secondary aerosol contribution to particulate pollution during haze events in China, Nature., 514, 218-222, https://doi.org/10.1038/nature13774, 2014.

Huang, X. D., Olmezi, I., Aras, N. K., and Gordon, G. E.: Emission of trace elements from motor- vehicles-potential maker elements and source composition profile, Atmos. Environ., 28, 13851391, https://doi.org/10.1016/1352-2310(94)90201-1, 1994.

Hunt, A., Jones, J., and Oldfield, F.: Magnetic measurements and heavy metals in atmospheric articulateres of anthropogenic origin, Sci. Total Environ., 33, 129-139, https://doi.org/10.1016/0048-9697(84)90387-5, 1984. 
Jordanova, D., Hoffmann, V., and Febr, K. T.: Mineralmagnetic characterization of anthropogenic magnetic phases in the Danube river sediments (Bulgarian part), Earth planet. Sc. Lett., 30, 7189, https://doi.org/10.1016/S0012-821X(04)00074-3, 2004.

Jordanova, D., Jordanova, N., and Petrov, P.: Magnetic susceptibility of road deposited sediments at a national scale-relation to population size and urban pollution, Environ. Pollut., 189, 239251, https://doi.org/10.1016/j.envpol.2014.02.030, 2014.

Kan, H., London, S. J., Chen, G., Zhang, Y., Song, G., Zhao, N., Jiang, L., and Chen, B.: Differentiating the effects of fine and coarse particles on daily mortality in Shanghai, China, Environ. Int., 33, 376-384, https://doi.org/10.1016/j.envint.2006.12.001, 2007.

Kardel, F., Wuyts, K., Mahe, B. A., and Samson, R.: Intra-urban spatial variation of magnetic particles: Monitoring via leaf saturation isothermal remanent magnetisation (SIRM), Atmos. Environ., 55, 111-120, https://doi.org/10.1016/j.atmosenv.2012.03.025, 2012.

Kim, W., Doh, S. J., Park, Y. H., and Yun, S. T.: Two-year magnetic monitoring in conjunction with geochemical and electron microscopic data of roadside dust in Seoul, Korea, Atmos. Environ., 41, 7627-7641, https://doi.org/10.1016/j.atmosenv.2007.05.050, 2007.

Kim, W., Doh, S. J., and Yu, Y. J.: Anthropogenic contribution of magnetic particulates in urban roadside dust, Atmos. Environ., 43, 3137-3144, https://doi.org/10.1016/j.atmosenv.2009.02.056, 2009.

Koukouzas, N., Hämäläinen, J., Papanikolaou, D., Tourunen, A., and Jäntti, T.: Mineralogical and elemental composition of fly ash from pilot scale fluidised bed combustion of lignite, bituminous coal, wood chips and their blends, Fuel., 86, 2186-2219, https://doi.org/10.1016/j.fuel.2007.03.036, 2007.

Kutchko, B. G. and Kim, A. G.: Fly ash characterization by SEM-EDS, Fuel., 85, 2537-2544, https://doi.org/10.1016/j.fuel.2006.05.016, 2006.

Lee, S. H., Murphy, D. M., Thomson, D. S., and Middlebrook, A. M.: Chemical components of single particles measured with Particle Analysis by Laser Mass Spectrometry (PALMS) during the Atlanta Supersite Project: Focus on organic/sulfate, lead, soot, and mineral particles, J. Geophys. Res.-Atmos., 107, AAC1-1AAC1-13, https://doi.org/10.1029/2000JD000011, 2002.

Lee, P. K., Choi, B. Y., and Kang, M. J.: Assessment of mobility and bio-availability of heavy metals in dry depositions of Asian dust and implications for environmental risk, Chemosphere., 119, 1411-1421, https://doi.org/10.1016/j.chemosphere.2014.10.028, 2015.

Li, G. J., Chen, J., Ji, J. F., Yang, J., and Conway, T. M.: Natural and anthropogenic sources of East Asian dust, Geology., 37, 727730, https://doi.org/10.1130/G30031A.1, 2009.

Li, P., Perreau, K. A, Covington, E., Song, C. H., Carmichael, G. R., and Grassian, V. H.: Heterogeneous reactions of volatile organic compounds on oxide particles of the most abundant crustal elements: surface reactions of acetaldehyde, acetone, and propionaldehyde on $\mathrm{SiO}_{2}, \mathrm{Al}_{2} \mathrm{O}_{3}, \mathrm{Fe}_{2} \mathrm{O}_{3}$, $\mathrm{TiO}_{2}$, and $\mathrm{CaO}$, J. Geophys. Res.-Atmos., 106, 5517-5529, https://doi.org/10.1029/2000JD900573, 2001.

Liu, Q. S., Roberts, A. P., Larrasoaña, J. C., Banerjee, S. K., Guyodo, Y., Tauxe, L., and Oldfield, F.: Environmental Mag- netism: Principles and Applications, Rev. Geophys., 50, 1-50, https://doi.org/10.1029/2012RG000393, 2012.

Liu, Q. S., Sun, Y. B., Qiang, X. K., Tada, R., Hu, P.X., Duan, Z. Q., Jiang, Z. X., Liu, J. X., and Su, K.: Characterizing magnetic mineral assemblages of surface sediments from major Asian dust sources and implications for the Chinese loess magnetism, Earth Planets Space., 67, 61, https://doi.org/10.1186/s40623015-0237-8, 2015.

Lu, X., Zhang, X., Li, L. Y., and Chen, H.: Assessment of metals pollution and health risk in dust from nursery schools in Xi'an, China, Environ. Res., 128, 27-34, https://doi.org/10.1016/j.envres.2013.11.007, 2014.

Maher, B. A.: Magnetic properties of modern soils and Quaternary loessic palaeosols: palaeoclimatic implications, Palaeogeogr. Palaeocl., 137, 25-54, https://doi.org/10.1016/S00310182(97)00103-X, 1998.

Maher, B. A.: Rain and dust: magnetic records of climate and pollution, Elements., 5, 229-234, https://doi.org/10.2113/gselements.5.4.229, 2009.

Maher, B. A. and Thompson, R.: Mineral magnetic record of the Chinese loess and paleosols, Geology., 19, 3-6, https://doi.org/10.1130/00917613(1991)019<0003:MMROTC>2.3.CO;2, 1991.

Maher, B. A., Moore, C., and Matzka, J.: Spatial variation in vehicle-derived metal pollution identified by magnetic and elemental analysis of roadside tree leaves, Atmos. Environ., 42, 364-373, https://doi.org/10.1016/j.atmosenv.2007.09.013, 2008.

Maher, B. A., Ahmed, I. A. M., Davison, B., Karloukovski, V., and Clarke, R.: Impact of Roadside Tree Lines on Indoor Concentrations of Traffic-Derived Particulate Matter, Environ. Sci. Technol., 47, 13737-13744, https://doi.org/10.1021/es404363m, 2013.

Marron, J. S.: What does optimal bandwidth selection mean for nonparametric regression estimation?, Department of Statistics, University of North Carolina at Chapel Hill, 1986.

Matzka, J. and Maher, B. A.: Magnetic biomonitoring of roadside tree leaves: identification of spatial and temporal variations in vehicle-derived particulates, Atmos. Environ., 33, 4564-4569, https://doi.org/10.1016/S1352-2310(99)00229-0, 1999.

Meza-Figueroa, D., De la O-Villanueva, M., and De la Parra, M. L.: Heavy metal distribution in dust from elementary schools in Hermosillo, Sonora, Mexico, Atmos. Environ., 41, 276-288, https://doi.org/10.1016/j.atmosenv.2006.08.034, 2007.

Moreno, E., Sagnotti, L., Dinares-Turell, J., Winkler, A., and Cascella, A.: Biomonitoring of traffic air pollution in Rome using magnetic properties of tree leaves, Atmos. Environ., 37, 29672977, https://doi.org/10.1016/S1352-2310(03)00244-9, 2003.

Mudelsee, M.: Short note: CLIM-X-DETECT: A Fortran 90 program for robust detection of extremes against a time-dependent background in climate records, Comput. Geosci-UK., 32, 141144, https://doi.org/10.1016/j.cageo.2005.05.010, 2006.

Muxworthy, A. R., Matzka, J., and Petersen, N.: Comparison of magnetic parameters of urban atmospheric particulate matter with pollution and meteorological data, Atmos. Environ. 35, 4379-4386, https://doi.org/10.1016/S1352-2310(01)002503, 2001.

Nel, A., Xia, T., Madler, L., and Li, N.: Toxic potential of materials at the nanolevel, Science, 311, 622-627, https://doi.org/10.1126/science.1114397, 2006. 
Pacyna, J. M. and Pacyna, E. G.: An assessment of global and regional emissions of trace metals to the atmosphere from anthropogenic sources worldwide, Environ. Rev., 9, 269-298, https://doi.org/10.1139/a01-012, 2001.

Pant, P. and Harrison, R. M.: Estimation of the contribution of road traffic emissions to particulate matter concentrations from field measurements: A review, Atmos. Environ., 77, 78-97, https://doi.org/10.1016/j.atmosenv.2013.04.028, 2013.

Pickrell, J. A., Erickson, L. E., and Klabunde, K. J.: Toxicity of inhaled nanomaterials, in: Nanoscale Materials in Chemistry, 2nd edition, edited by: Klabunde, K. J. and Richards, R. M., published by John Wiley \& Sons, Inc., Hoboken, New Jersey, Chapter 22, 729-769, https://doi.org/10.1002/9780470523674.ch22, 2009.

Pike, C. R., Roberts, A. P., and Verosub, K. L.: Characterizing interactions in fine magnetic particle systems using first order reversal curves, J. Appl. Phys., 85, 6660-6667, https://doi.org/10.1063/1.370176, 1999.

Qian, G. Q. and Dong, J. B.: Discussions on different dust trapping methods and on some related Topics (in Chinese), J. Desert Res., 24, 779-782, 2004.

Qiao, Q. Q., Huang, B. C., Zhang, C. X., Piper, J. D. A., Pan, Y. P., and Sun, Y.: Assessment of heavy metal contamination of dustfall in northern China from integrated chemical and magnetic investigation, Atmos. Environ., 74, 182-193, https://doi.org/10.1016/j.atmosenv.2013.03.039, 2013.

Quayle, B. M., Mather, T. A., Witt, M. L. I., Maher, B. A., Mitchell, R., Martin, R. S., and Calabrese, S.: Application and evaluation of biomagnetic and biochemical monitoring of the dispersion and deposition of volcanically-derived particles at Mt. Etna, Italy, J. Volcanol. Geoth. Res., 191, 107-116, https://doi.org/10.1016/j.jvolgeores.2010.01.004, 2010.

Roberts, A. P., Pike, C. R., and Verosub, K. L.: First-order reversal curve diagrams: a new tool for characterizing the magnetic properties of natural samples, J. Geophys. Res., 105, 28461-28475, https://doi.org/10.1029/2000JB900326, 2000.

Rubasinghege, G. and Grassian, V. H.: Photochemistry of adsorbed nitrate on aluminum oxide particle surfaces, J. Phys. Chem. A., 113, 7818-7825, https://doi.org/10.1021/jp902252s, 2009.

Salvador, P., Artíñano, B., Alonso, D. G., Querol, X., and Alastuey, A.: Identification and characterisation of sources of $\mathrm{PM}_{10}$ in Madrid (Spain) by statistical methods, Atmos Environ., 38, 435447, https://doi.org/10.1016/j.atmosenv.2003.09.070, 2004.

Spassov, S., Egli, R., Heller, F., Nourgaliev, D. K., and Hannam, J.: Magnetic quantification of urban pollution sources in atmospheric particulate matter, Geophys. J. Int., 159, 555-564, https://doi.org/10.1111/j.1365-246X.2004.02438.x, 2004.

Stein, A. F., Draxler, R. R., Rolph, G.D., Stunder, B. J. B., Cohen, M. D., and Ngan, F.: NOAA's HYSPLIT atmospheric transport and dispersion modeling system, B. Am. Meterorl. Soc., 96, 2059-2077, https://doi.org/10.1175/BAMS-D-14-00110.1, 2015.

Sun, J. M., Zhang, M. Y., and Liu, T. S.: Spatial and temporal characteristics of dust storms in China and its surrounding regions, 1960-1999: relations to source area and climate, J. Geophys. Res., 106, 10325-10334, https://doi.org/10.1029/2000JD900665, 2001.

Sun, Y. B., Chen, H. Y., Tada, R., Weiss, D., Lin, M., Toyoda, S., Yan, Y., and Isozaki, Y.: ESR signal intensity and crystallinity of quartz from Gobi and sandy deserts in East Asia and implication for tracing Asian dust provenance, Geochem. Geophy. Geosy., 14, 2615-2627, https://doi.org/10.1002/ggge.20162, 2013.

Sushil, S. and Batra, V. S.: Analysis of fly ash heavy metal content and disposal in three thermal power plants in India, Fuel., 85, 2676-2679, https://doi.org/10.1016/j.fuel.2006.04.031, 2006.

Takeuchi, M., Deguchi, J., Sakai, S., and Anpo, M.: Effect of $\mathrm{H}_{2} \mathrm{O}$ vapor addition on the photocatalytic oxidation of ethanol, acetaldehyde and acetic acid in the gas phase on $\mathrm{TiO}_{2}$ semiconductor powders, Appl. Catal. B-Environ., 96, 218-223, https://doi.org/10.1016/j.apcatb.2010.02.024, 2010.

Urbat, M., Lehndorff, E., and Schwark, L.: Biomonitoring of air quality in the Cologne conurbation using pine needles as a passive sampler - Part I: magnetic properties, Atmos. Environ., 38, 3781-3792, https://doi.org/10.1016/j.atmosenv.2004.03.061, 2004.

Usher, C. R., Al-Hosney, H., Carlos-Cuellar, S., and Grassion, V. H.: A laboratory study of the heterogeneous uptake and oxidation of sulfur dioxide on mineral dust particles, J. Geophys. Res.-Atmos., 107, ACH16-1-ACH16-9, https://doi.org/10.1029/2002JD002051, 2002.

Vouk, V. B. and Piver, W. T.: Metallic elements in fossil fuel combustion products: amounts and form of emissions and evaluation of carcinogenicity and mutagenicity, Environ. Health Persp., 47, 201-225, https://doi.org/10.1289/ehp.8347201, 1983.

Wang, X., Dong, Z., Zhang, J., and Liu, L.: Modern dust storms in China: an overview, J. Arid Environ., 58, 559-574, https://doi.org/10.1016/j.jaridenv.2003.11.009, 2004.

Wehner, B., Birmili, W., Ditas, F., Wu, Z., Hu, M., Liu, X., Mao, J., Sugimoto, N., and Wiedensohler, A.: Relationships between submicrometer particulate air pollution and air mass history in Beijing, China, 2004-2006, Atmos. Chem. Phys., 8, 6155-6168, https://doi.org/10.5194/acp-8-6155-2008, 2008.

Welton, J. E.: SEM petrology Atlas. The American association of petroleum geologists, Oklahoma, USA, 1984.

Wilson, W. E., Chow, J. C., Claibom, C., Fusheng, W., Engelbrecht, J., and Watson, J. G.: Monitoring of particulate matter outdoors, Chemosphere., 49, 1009-1043, https://doi.org/10.1016/S00456535(02)00270-9, 2002.

Wu, L. Y., Tong, S. R., Wang, W. G., and Ge, M. F.: Effects of temperature on the heterogeneous oxidation of sulfur dioxide by ozone on calcium carbonate, Atmos. Chem. Phys., 11, 65936605, https://doi.org/10.5194/acp-11-6593-2011, 2011.

Xie, S., Dearing, J. A., Bloemendal, J., and Boyle, J. F.: Association between the organic matter content and magnetic properties in street dust, Liverpool, UK, Total Environ., 241, 205-214, https://doi.org/10.1016/S0048-9697(99)00346-0, 1999.

Yan, Y., Sun, Y., Weiss, D., Liang, L. J., and Chen, H. Y.: Polluted dust derived from long-range transport as a major end member of urban aerosols and its implication of non-point pollution in northern China, Total Environ., 506-507, 538-545, https://doi.org/10.1016/j.scitotenv.2014.11.071, 2015a.

Yan, Y., Sun, Y., Ma, L., and Long, X,: A multidisciplinary approach to trace Asian dust storms from source to sink, Atmos. Environ., 105, 43-52, https://doi.org/10.1016/j.atmosenv.2015.01.039, $2015 b$.

Zdanowicz, C., Hall, G., Vaive, J., Amelin, Y., Percival, J., Girard, I., Biscaye, P., and Bory, A.: Asian dustfall in the St. Elias Moun- 
tains, Yukon, Canada, Geochim. Cosmochi. Act., 70, 3493-3507, https://doi.org/10.1016/j.gca.2006.05.005, 2006.

Zhang, C. X., Qiao, Q. Q., Piper, J. D. A., and Huang, B. C.: Assessment of heavy metal pollution from a Fe-smelting plant in urban river sediments using environmental magnetic and geochemical methods, Environ. Pollut., 159, 3057-3070, https://doi.org/10.1016/j.envpol.2011.04.006, 2011.

Zhang, C. X., Qiao, Q. Q., Appe,1 E., and Huang, B. C.: Discriminating sources of anthropogenic heavy metals in urban street dusts using magnetic and chemical methods, J. Geochem. Explor., 119-120, 60-75, https://doi.org/10.1016/j.gexplo.2012.06.014, 2012a.
Zhang, C. X., Erwin, A., and Qiao, Q. Q.: Heavy metal pollution in farmland irrigated with river water near a steel plant - magnetic and geochemical signature, Geophys. J. Int., 192, 963-974, https://doi.org/10.1093/gji/ggs079, 2012b.

Zhang, R., Wang, M., Zhang, X., and Zhu, G.: Analysis on the chemical and physical properties of particles in a dust storm in spring in Beijing, Powder Technol., 137, 77-82, https://doi.org/10.1016/j.powtec.2003.08.056, 2003.

Zheng, Z. G. and Yang, Y.: Cross-validation and median criterion, Stat. Sinica., 8, 907-921, 1998. 